appear to be of the RII category. Though we have seen several other patients with apparent chloroquine resistance, either they have been too ill to delay alternative treatment or they have had several courses of chloroquine before testing for resistance and have finally responded to the test course. It is now our practice to use chloroquine by mouth in a dose of $10 \mathrm{mg} / \mathrm{kg}$, repeated after six hours, then daily for three days. This is the general dosage by WHO recommended standards. ${ }^{2}$

We believe that chloroquine resistance is appearing in Zambia and that clinicians must watch for this. In such cases we have had success with a combination of doxycycline and quinine or chloroquine.

${ }^{1}$ World Health Organisation, Resistance of Malaria Parasites to Drugs. WHO Technical Report No 296, 1965.

2 World Health Organisation, Chemotherapy of Malaria. WHO Technical Series No 375, 1967.

(Accepted 2 March 1978)

Department of Paediatrics and Child Health, University Teaching Hospital, PO Box R W 110, Lusaka, Zambia

A A KHAN, MB, FRCP, professor

M J MAGUIRE, MB, MRCP, honorary lecturer

\section{Predicting plasma concentrations of common biochemical values from residual peritoneal fluid in patients on peritoneal dialysis}

Peritoneal dialysis is now widely used in the management of renal failure. Since frequent blood sampling is needed to assess the adequacy of dialysis, we decided to investigate whether equilibrated peritoneal fluid could be used instead of blood samples to monitor biochemical values in patients being treated with peritoneal dialysis.

\section{Patients, methods, and results}

Fifteen patients being treated with maintenance peritoneal dialysis were studied. Dialysis was for an average of 40 hours a week by an indwelling soft catheter. Each morning before starting dialysis, blood and peritoneal fluid samples were taken simultaneously, the latter directly from the peritoneal cavity after discarding the first $2 \mathrm{ml}$ from the catheter. Both samples were analysed for concentrations of urea, creatinine, sodium, potassium, calcium, phosphate, total protein, and albumin using standard techniques.

The table shows the highly significant correlations between plasma and peritoneal fluid concentrations of creatinine, urea, sodium, potassium, calcium, and phosphate. Plasma calcium concentrations can be closely

Correlation between peritoneal fluid and plasma concentrations of some common biochemical parameters

\begin{tabular}{|c|c|c|c|c|c|}
\hline & $\begin{array}{l}\text { No of } \\
\text { tests }\end{array}$ & $\begin{array}{c}\text { Plasma } \\
(\text { mean } \pm S D)\end{array}$ & $\begin{array}{c}\text { Peritoneal } \\
\text { fluid } \\
\text { (mean } \pm S D)\end{array}$ & $\begin{array}{l}\text { Signifi- } \\
\text { cance of } \\
\text { difference } \\
(\mathbf{P})^{*}\end{array}$ & $\begin{array}{c}\text { Correlation } \\
\text { coefficient } \\
(\mathrm{r}) \dagger\end{array}$ \\
\hline $\begin{array}{l}\text { Urea }(\mathrm{mmol} / \mathrm{l}) \\
\text { Creatinine }(\mu \mathrm{mol} / \mathrm{l}) \\
\mathrm{Na}^{+}(\mathrm{mmol} / \mathrm{l}) \\
\mathrm{K}^{+}(\mathrm{mmol} / \mathrm{l}) \\
\text { Calcium }(\mathrm{mmol} / \mathrm{l}) \\
\text { Calcium }(\mathrm{mmol} / \mathrm{l}) \\
\text { Phosphate }(\mathrm{mmol} / 1) \\
\text { Protein }(\mathrm{g} / \mathrm{l}) \\
\text { Albumin }(\mathrm{g} / \mathrm{l}) \\
\mathrm{A}: \mathrm{G} \text { ratio }\end{array}$ & $\begin{array}{l}35 \\
35 \\
35 \\
35 \\
29 \\
29 \\
29 \\
19 \\
19 \\
19\end{array}$ & $\begin{array}{r}31 \cdot 26 \pm 8.48 \\
1335 \pm 666 \\
136 \cdot 62 \pm 3 \cdot 31 \\
4.48 \pm 0.89 \\
2 \cdot 23 \pm 0 \cdot 25 \\
2 \cdot 23 \pm 0 \cdot 25 \\
1 \cdot 84 \pm 0.87 \\
59 \cdot 97 \pm 7.39 \\
26 \cdot 76 \pm 4 \cdot 00 \\
0.809 \pm 0 \cdot 10\end{array}$ & $\begin{array}{c}31.43 \pm 8.50 \\
1338 \pm 691 \\
136.34 \pm 4.91 \\
4.46 \pm 0.97 \\
1.73 \pm 0.25 \\
2.23=0.25 \\
1.85+0.91+ \\
25.15 \pm 7.85 \\
11.81 \pm 4.59 \\
0.899 \pm 0.30\end{array}$ & $\begin{array}{l}\text { NS } \\
\text { NS } \\
\text { NS } \\
\text { NS } \\
<0 \cdot 001 \\
\text { NS } \\
\text { NS } \\
<0 \cdot 001 \\
<0 \cdot 001 \\
\text { NS }\end{array}$ & $\begin{array}{l}0.99 \\
0.99 \\
0.81 \\
0.96 \\
0.93 \\
0.93 \\
0.99 \\
0.83 \\
0.75\end{array}$ \\
\hline
\end{tabular}

*Calculated by means of paired $t$ test.

tBetween plasma and peritoneal fluid concentrations.

† Calculated mean based on regression equation $\mathrm{y}=\mathrm{x}+0 \cdot 5$, where $y$ represents plasma and $x$ peritoneal fluid calcium concentrations.

NS = Not significant.

Conversion: SI to traditional units-Urea: $1 \mathrm{mmol} / 1 \approx 6.02 \mathrm{mg} / 100 \mathrm{ml}$. Creatinine: $1 \mu \mathrm{mol} / 1 \approx 0.011 \mathrm{mg} / 100 \mathrm{ml}$. Na, $\mathrm{K}: 1 \mathrm{mmol} / 1=1 \mathrm{mEq} / \mathrm{l}$. Calcium: $1 \mathrm{mmol} / 1 \approx 4$ $\mathrm{mg} / 100 \mathrm{ml}$. Phosphate: $1 \mathrm{mmol} / 1 \approx 3.1 \mathrm{mg} / 100 \mathrm{ml}$. approximated by adding $0.5 \mathrm{mmol} / 1(2 \mathrm{mg} / 100 \mathrm{ml})$ to peritoneal fluid calcium concentrations. Nevertheless, the margin of error for plasma calcium lay between $\pm 7.8 \%$. Proteins also tended to equilibrate across the peritoneal membrane. There was no appreciable difference between plasma and peritoneal fluid albumin to globulin ratios.

\section{Comment}

Several points clearly emerged. Peritoneal fluid concentrations of urea, creatinine, sodium, potassium, and phosphate approximated to their plasma concentrations after at least an overnight equilibration. For practical purposes the two concentrations may be regarded as identical. While complete equilibration for calcium cannot be achieved after overnight equilibration, calcium concentrations in plasma and peritoneal fluid correlated closely enough to validate estimations of plasma calcium from peritoneal fluid. In fact complete equilibration of ionised calcium between plasma and peritoneal fluid is probably achieved after overnight equilibration, as peritoneal clearance of ionised calcium is similar to that of urea.

These findings show that routine blood sampling can be abandoned in patients on peritoneal dialysis in favour of peritoneal fluid analysis, and furthermore, sampling can easily be done by the patients with instruction. Sampling peritoneal fluid rather than blood eliminates an obvious cause of blood loss and prevents damage to sites of blood access. Samples may be mailed without fear of distortion of potassium and phosphate concentrations by leakage from damaged red cells.

An intriguing aspect of this study is the fact that the peritoneal membrane appears to be highly and non-selectively permeable to large protein molecules. The finding of similar albumin to globulin ratios in plasma and peritoneal fluid agrees with those of other studies on immunoglobulin loss in peritoneal dialysis. ${ }^{2}$ Protein loss is a familiar hazard of peritoneal dialysis, and our results suggest that it is caused by equilibration across the peritoneum rather than by some illunderstood irritation of the membrane. The good correlations between plasma and peritoneal fluid concentrations of total protein and albumin after overnight equilibration help to explain the increased protein loss in the first few cycles of each dialysis. ${ }^{3}$ It is impracticable to try to derive an equation to predict plasma protein concentrations from those in peritoneal fluid, but will be of interest to measure hormones such as thyroxine in the peritoneal fluid after overnight equilibration to see if losses by such a route contribute to the increased incidence of subclinical hypothyroidism in patients treated with peritoneal dialysis. ${ }^{4}$

Requests for reprints to $\mathrm{Dr}$ M K Chan.

${ }^{1}$ Stoltz, M L, Nolph, K D, and Maher, J F, fournal of Laboratory and Clinical Medicine, 1971, 78, 389.

${ }^{2}$ McKelvey, E M, et al, Archives of Internal Medicine, 1974, 134, 266.

${ }^{3}$ Bianchi, R, et al, European fournal of Clinical Investigations, 1975, 5, 409.

Boss, A M B, et al, European Dialysis and Transplant Association, XIII Congress, abstract, p 299.

(Accepted 23 February 1978)

Department of Nephrology and Transplantation, Royal Free Hospital, London NW3 2QG

$M$ K CHAN, MB, MRCP, registrar

Y C HUANG, MB, BS, senior house officer

$Z$ VARGHESE, MSC, chief biochemist

R A BAILLOD, MB, BS, first assistant

J F MOORHEAD, MB, FRCP, director

\section{Correction}

\section{Creamatocrit}

In the article by Dr A Lucas and others (22 April, $p$ 1018) the formula for the relation between creamatocrit reading and energy content of human milk should have read: $\mathrm{kcal}=290+(66.8 \times$ creamatocrit $(\%))$.

\section{Serum lipid concentrations in obesity}

In the paper by Dr R G Wilcox (10 June, p 1513) the key in the legend to fig 2 was printed incorrectly. It should have read: $x---\times=$ Weight. $0=$ Cholesterol. $\mathrm{O}-\mathrm{O}=$ Triglyceride .

.

(1)

